\title{
A tool for evaluating geothermal power exploitability and its application to Ischia, Southern Italy
}

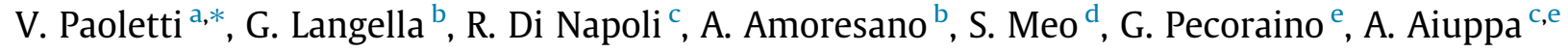 \\ a Dipartimento di Science della Terra, dell'Ambiente e delle Risorse, University "Federico II" of Naples, Largo S. Marcellino, 10, 80138 Naples, Italy \\ ${ }^{\mathrm{b}}$ Department of Industrial Engineering - University "Federico II" of Naples, Via Claudio, 21, 80125 Naples, Italy \\ c Dipartimento di Scienze della Terra e del Mare (DiSTeM), Università degli Studi di Palermo, Via Archirafi, 26, 90123 Palermo, Italy \\ ${ }^{\mathrm{d}}$ Dipartimento di Ingegneria Elettrica e Tecnologia dell'Informazione - University "Federico II" of Naples, Via Claudio, 21, 80125 Naples, Italy \\ e Istituto Nazionale di Geofisica e Vulcanologia, Sezione di Palermo, Via Ugo La Malfa, 153, 90146 Palermo, Italy
}

\section{H I G H L I G H T S}

- A method to evaluate the potential for electric power production at geothermal sites.

- It evaluates geofluid's flow rate, pressure, temperature and non-condensable gases.

- It defines the best plant option and finally returns the actual available power.

\section{A R T I C L E I N F O}

\section{Article history:}

Received 13 June 2014

Received in revised form 29 September 2014

Accepted 4 November 2014

Available online 25 November 2014

\section{Keywords:}

Geothermal power plants

Geothermal exergy

Ischia volcanic island

\begin{abstract}
A B S T R A C T
The paper proposes a method to evaluate the potential for electric power production at any site of possible geothermal interest. Accounting for geological data of the reservoirs, the method allows the computation of the available electrical power of the investigated site. Electrical energy production from geothermal sources is realized through different techniques, such as single flash and double flash, dry steam, and binary ORC plants. The technique chosen to be the most productive is determined by analyzing a specific range of geofluid properties, mainly temperature and pressure. Moreover, each plant typology has a global efficiency that may be correlated to geofluid enthalpy by empiric relations available in literature. The proposed evaluation method brings together all these correlations, yielding the power availability from a geosource, once its temperature and pressure are known. The method takes as input the geofluid available flow rate, its pressure, temperature and non-condensable gas content. It defines the best plant option from these parameters, calculates its global efficiency and finally returns the actual available power. For sites of geothermic interest, such as the volcanic island of Ischia in Southern Italy, the results of the application of this new method clearly highlight the most suitable zones for power plants installations.
\end{abstract}

(ㄷ) 2014 Elsevier Ltd. All rights reserved.

\section{Introduction}

Within the world scenario of renewable energy exploitation, geothermal energy has undergone a rapid increase in recent years. The total geothermal power installed worldwide is growing at a sustained rate of $4-5 \%$ per year. Presently, it amounts to $12,000 \mathrm{MW}$ and it could reach about $13,450 \mathrm{MW}$ of nameplate capacity by 2017 [1]. This value is predicted to increase when considering the compelling need to exploit natural energy resources as alternatives to fossil fuels. Geothermal energy is considered one of the most reliable and relatively least-expensive sources of renewable energy. A geothermal plant's initial cost is

\footnotetext{
* Corresponding author.

E-mail address: paoletti@unina.it (V. Paoletti).
}

generally high but running costs are relatively low and energy availability is continuous, free and long-lasting. Thus the plant can recover initial cost. Cost recovery time is strongly dependent on national incentive policies, ranging on average between three and ten years. Over the last decades we observed a slight improvement of geothermal plant efficiencies, but this has often implied elaborate and expensive energy conversion systems [2].

In this study we deal with the production of electricity from a geothermal source. Power generation is possible starting from minimum values of geothermal fluid at $300 \mathrm{~kJ} / \mathrm{kg}$ and $70^{\circ} \mathrm{C}$, for enthalpy and temperature respectively. Lower values imply low power efficiencies, defined as:

$\eta=\frac{W_{e}}{\dot{m} \cdot h}$ 
where $W_{e}$ is the electrical power output (kWe), is the total mass flow rate of geothermal fluid and $h$ is the reservoir enthalpy. Different geothermal plant typologies are available. The best choice is determined by reservoir enthalpy. Efficiencies increase with reservoir enthalpy but they are much lower than conventional plants such as gas fired or nuclear ones. In order to get a reliable feasibility analysis it is very important to know the plant efficiency. Commonly, an average efficiency of $10 \%$, varying from $1 \%$ to $20 \%$ is assumed. Lowest values refer to binary plants [1,3-5] whereas highest ones are related to dry steam plants [6,7].

Zarrouk et al. [8] performed a worldwide review of about 100 geothermal power plants, giving power conversion relations for single flash/dry steam plants, double flash plants and binary plants. They take into account the main factors affecting efficiency, expressed as non-condensable gas content (NCG), parasitic load, heat losses in pipes, turbine efficiency, generator efficiency, and last but not least, thermodynamic cycle efficiency. Concerning the last fundamental parameter, defined as the ratio between useful work and provided heat, the authors found values up to $16 \%$ for single flash and dry steam, $15 \%$ for double flash, and about $10 \%$ for binary ORC plants.

Many studies about thermodynamic cycle optimization of these plants were performed. Their purpose was to improve cycling efficiencies, the most recent [9-11], being for single flash, double flash and binary respectively. Moreover, a number of more complex plant configurations were studied and proposed in literature. Such as binary cycle with recuperator, dual-pressure binary cycle, dualfluid binary, Kalina binary cycles, hybrid and combined cycle plants and trilateral flash [8]. In each case, suggesting the best plant option for geothermal resource exploitation.

Due to the large variety of plant solutions, an integrated approach to the complexity of the geothermal phenomena is still lacking. Geothermal energy is a particular renewable source. Its use is sustainable only under certain conditions, which must be known particularly by investors and market players [12]. One of the most important issues is certainly the lifetime of a plant which varies differently from hydroplants. This is particularly the case of the geothermal binary plants. For those plants, a variation of the resource properties (temperature and pressure) may actually cause a fast end to the plant's life. Thus, the first and most important activity when designing a geothermal energy plant is an accurate investigation of the geothermal potential assessment, choosing a proper siting of the production and reinjection wells, and the prevision of their mutual interference. This allows a prediction of reservoir response at given industrial exploitation configurations (e.g., $[13,14])$.

The first classification criteria for geothermal resources are by temperature or by enthalpy; distinguished by low, medium and high enthalpy resources. The reference temperature is the average reservoir temperature measured in exploration wells, or by other up-to-date geothermic techniques [15]; by analyzing satellite images, applying a number of geo-indicators and performing 2D electric geophysical surveys. Nevertheless, temperature by itself is not a good classification parameter of the resource, especially when power production potential is sought. Exergy, as maximum work available interacting with the environment, is a more significant parameter to classify geothermal resources, as widely reported in literature (e.g. [16]). The available flow rate of geo-fluid is a key parameter also. Many reservoirs have low enthalpy but considerable water flow, and thus, may be of interest for power production investment.

The present work aims to be a useful tool to quantify the power potential of a geothermal site. Our study is focused on low enthalpy geothermal resources starting from $300 \mathrm{~kJ} / \mathrm{kg}$ and $70^{\circ} \mathrm{C}$. For these reservoirs, the best choice for power production is a binary plant based on the organic Rankine cycle [16]. Nevertheless, the analysis proposed is applicable to higher enthalpy cases also; taking into account the best available technology for specific enthalpy ranges. Starting from exergetic potential of resources, the method we propose considers other key parameters, such as reservoir depth, and content in the aquifer of non-condensable gas.

Starting from data acquired by geophysical and geological and geochemical investigations, the method allows for the identification of zones where power production may be feasible and effective.

\section{Exergy and available power of geothermal resource}

The classification of geothermal resources by geofluid temperature or by its enthalpy may not provide exhaustive information about the work that can be produced by them. In fact, at least two independent thermodynamic properties are needed to define the quality of energy content from a geothermal fluid. Usually temperature and pressure are adopted, and each by themselves, cannot identify the highest potential for producing work. For example, a geofluid with a temperature lower than another geofluid could have a higher potential for power production, if its pressure is high enough. Exergy is certainly the most appropriate theoretical parameter for determining unambiguously the mechanical energy achievable by a geothermal source, as widely reported in literature [17-19]).

It is well known that exergy is the maximum useful work deliverable by a system undergoing a reversible process from the specified initial thermodynamic state to the state of its environment, i.e. the dead state [16]. Specific exergy (ex) represents a thermodynamic property can be expressed by the formula:

$e x=h-h_{0}-T_{0} \cdot\left(s-s_{0}\right)$

where $h$ is the specific enthalpy $(\mathrm{kJ} / \mathrm{kg}), s$ the specific entropy $(\mathrm{kJ} / \mathrm{kg} \mathrm{K}), T$ the temperature $(\mathrm{K})$ and zero indicates the dead state conditions.

Any mass flow $\dot{m}(\mathrm{~kg} / \mathrm{s})$ is associated with an exergy flow $\dot{E} x$ $(\mathrm{kW})$. Exergy flow is the maximum useful mechanical power deliverable by a fluid flow rate undergoing a reversible process from the specified initial thermodynamic state to the state of its environment, i.e. the dead state.

Exergy flow can be expressed by:

$\dot{E} x=\dot{m} \cdot e x$

There are different ways for exergy flow to be produced, depending on the mode of interaction with the surrounding environment. If the interaction is a heat exchange at constant pressure, the maximum work obtainable in a reversible process is:

$e x=\left(h-h_{0}\right) \cdot\left(1-T_{0} \cdot \frac{\left(s-s_{0}\right)}{\left(h-h_{0}\right)}\right)=q \cdot\left(1-\frac{T_{0}}{T}\right)$

where $q(\mathrm{~kJ} / \mathrm{kg})$ is the reversible heat exchanged at a constant source temperature $T(\mathrm{~K})$ for mass unit. The exergy flow in this case is given by:

$\dot{E} x=\dot{m} \cdot q \cdot\left(1-\frac{T_{0}}{T}\right)$

This is the typical case of binary plants where the geo-fluid transfers heat to the organic fluid used in the power cycle.

In the case of high-enthalpy vapour-dominated reservoirs, power production can be realized by expansion of geo-fluid, so specific exergy and exergy flow can be expressed by Refs. (2) and (3) respectively, referring to the reference state zero for enthalpy and entropy.

The electrical power $\dot{W}_{e}$ available from exergy flow $\dot{E} x$ is a fraction of it and is affected by all energy losses involved in the energy conversion process, from water production to its reinjection, 
as reported in the next paragraph. Moreover, $\dot{W}_{e}$ depends on the geothermal power plant typology, varying from binary plants to dry steam plants, as reservoir enthalpy ranges from 300 to $2500 \mathrm{~kJ} / \mathrm{kg}$.

\section{The method}

We calculate the available power achievable and the associated option for optimal plant by the following relation:

$\dot{W}_{e}=k_{\text {gas }} \cdot \dot{m} \cdot\left(h_{a q}-\Delta h_{t l}-h_{r w}\right) \cdot \eta_{g}$

where $\Delta h_{t l}$ is an enthalpy loss related to depth of the geofluid aquifer, $k_{\text {gas }}$ accounts for gas content in water, mainly $\mathrm{CO}_{2}, \mathrm{O}_{2}$ and $\mathrm{N}_{2}, \dot{m}$ is the ground water production rate. The variables $h_{a q}$ and $h_{r w}$ are the enthalpies of water at aquifer condition and at reinjection well and $\eta_{g}$ is the global efficiency of the plant.

Eq. (6) is derived from a well-known general equation giving the electrical power $\dot{W}_{e}$ available from a thermal power $\dot{Q}$, according to a global efficiency $\eta_{g}$ :

$\dot{W}_{e}=\dot{Q} \cdot \eta_{g}$

In the examined case, the thermal power is given by the product between the flow rate and the geofluid enthalpy gap. The actual flow rate of geofluid is affected by the non-condensable gas content. In our analysis, such gas content is considered a "void fraction" $k_{\text {gas }}$ which lowers the water mass flow rate. Thus, the flow rate that really contributes to thermal exchange is given by product between $\dot{m}$ and $k_{\text {gas }}$. We evaluated the geofluid enthalpy gap as the difference between geofluid enthalpy $h_{a q}$ and reinjection enthalpy $h_{r w}\left(h_{a q}-h_{r w}\right)$. This gap is then reduced by the enthalpy loss $\Delta h_{t l}$ related to aquifer depth.

The starting point of our method are the maps of the following geological/physical and geochemical data related to water at the top of the reservoir: (i) content of non-condensable gases (NCG), (ii) well depth; (iii) available flow rate at wells; (iv) temperature; (v) pressure. By these parameters we calculate the terms of Eqs. (2) and (6), as described in the next paragraphs.

Temperature and pressure of ground water are key parameters as they determine the geothermal fluid enthalpy $h_{a q}$ which is directly involved in the available power calculation (Eq. (6)). We considered the pressure and temperature of the aquifer top and evaluated $h_{a q}$ using the Refprop database software (http:// www.nist.gov/). In the following we shall describe the influence of NCG, temperature, well depth and flow rate.

\subsection{Non-condensable gases content influence}

Non-condensable gases (NCG) in ground water or steam are mainly $\mathrm{CO}_{2}, \mathrm{O}_{2}, \mathrm{~N}_{2}$ and $\mathrm{H}_{2} \mathrm{~S}$. Their influence on power production is different depending on plant configuration. In binary plants, ground water or steam does not produce work by expansion but instead, transfers heat to an organic fluid which evolves according to a Rankine cycle. In this case gas content affects the thermal power that ground water can transfer to an organic fluid. Referring to volume content $C_{\text {gas }}\left(\mathrm{cm}^{3} / \mathrm{l}\right)$ of NCG in water, and considering that 11 of water corresponds to about $1 \mathrm{~kg}$, the $k_{\text {gas }}$ coefficient of Eq. (6) can be evaluated by:

$k_{\text {gas }}=1-\frac{C_{\text {gas }}}{1000}$

This relation shows that, due to its negligible density with respect to water, gas content gives no contribution to heat exchange, but it lowers it proportionally to its content.

In single flash and double flash plants, its the geothermal fluid itself which produces work by expansion. In this case NCG degrades the quality of the steam and increases corrosion. This also requires increased power consumption to remove these gases from the power plant condenser. NCG mainly consists of carbon dioxide $\left(\mathrm{CO}_{2}\right)$, hydrogen sulfide $\left(\mathrm{H}_{2} \mathrm{~S}\right)$ and some other gases in negligible quantities. Gas content refers to steam, which ranges from almost zero to about $15 \%$ by weight, in some geothermal fields. The gas lowers power efficiency because it decreases the specific expansion work in the turbine thus hampering performance [20]. Hudson [21] evaluated that steam containing non-condensable gases of $1 \%$ by weight reduces the power output by $0.59 \%$ in comparison with steam without NCG. Adopting this result for single and double flash plants, we evaluated the $k_{\text {gas }}$ coefficient by:

$k_{\text {gas }}=1-0.0059 \cdot C_{\text {gas } \%}$

where $C_{\text {gas\% }}$ is the percentage concentration (unit less).

\subsection{Well depth influence}

Of course, well depth has a strong influence on drilling costs but also on energy balance $[22,23]$. Two main energy losses should be considered. The first is related to the work needed to pump geofluid up through the well. In the standard configuration being adopted, we took into account a reinjection so only head losses contribute to pump power required. The second loss is mainly a thermal loss due to heat exchange between water and ground while water is pumped up.

The first loss is incorporated within global efficiency $\eta_{g}$, whereas the $\Delta h_{t l}$ term accounts for the second loss. Thermal loss depends on water temperature and depth and pipe insulation. In our analysis we used a mean value of $0,2 \mathrm{~kJ} / \mathrm{kg} \cdot \mathrm{m}$, substantiated by data from installed plants around the world [8].

Well depth $L_{w}$ is a fundamental parameter for ground water pressure and enthalpy calculation. In order to evaluate the water pressure $p, L_{w}$ should be coupled with ground water static head $H_{s}$, i.e., the water level depth from the top of the well when in a static condition. $H_{s}$ differs from the dynamic water level $H_{d}$, measured when water flows. Water pressure can be evaluated as follows:

$p($ bar $)=\left(L_{w}-H_{s}\right) / 10.20$

\subsection{Ground water flow rate influence}

Ground water flow rate ( $\dot{m}$ in Eq. (6)) is certainly the most variable parameter in our analysis and has a fundamental weight in the exploitable power calculation. The high enthalpy level of geothermal water does not imply a considerable exploitable power if an exiguous flow rate is available. On the other hand a low enthalpy level of geothermal fluid may lead to a highly exploitable power if a considerable flow rate is available.

Often, information about the amount of ground water available at a particular location and its quality, rely on prior knowledge of the local geofluid system, experience in similar areas and a diverse array of information; such as land surface topography, local vegetation, rock fracturing (where applicable), local geology, geofluid chemistry, information on thickness, depth and the permeability of local aquifers from existing wells. Geofluid levels, satellite or aerial photographs, and geophysical measurements complete the array of information.

\subsection{Exergy and exploitable power calculation}

Following [8], the best plant configuration would be chosen depending on the enthalpy level, namely $h_{a q}$. The binary plant is suitable for enthalpy from 300 to $1000 \mathrm{~kJ} / \mathrm{kg}$. A double flash plant addresses enthalpy from 700 to $1800 \mathrm{~kJ} / \mathrm{kg}$ and either single flash 
or dry steam installations are suitable for enthalpy from 800 to $2500 \mathrm{~kJ} / \mathrm{kg}$. For enthalpy levels falling into two or three plants configurations, all of them are evaluated and compared, giving in output, the best solution in terms of available electrical power.

For each plant configuration, the exploitable power can be evaluated by Eq. (6), but with different values of global efficiency $\eta_{g}$ of the plant. This key parameter can be considered as a function of geothermal fluid enthalpy. In the present model we used the functions proposed by Ref. [8], which were derived on the basis of worldwide plants efficiency data.

Such functions, expressing efficiency as a function of aquifer enthalpy, are reported below:

$\eta_{g}=8.7007 \cdot \ln \left(h_{a q}\right)-52.335$

$\eta_{g}=10.166 \cdot \ln \left(h_{a q}\right)-61.68$ $\eta_{g}=6.6869 \cdot \ln \left(h_{a q}\right)-37.929$

They refer respectively to single flash and dry steam plants (Eq. (11)), double flash plants (Eq. (12)) and binary plants (Eq. (13)).

Exergy is a meaningful parameter about the capability of ground water to produce work. Nevertheless, it is a specific parameter giving no information about flow rate and power. It is also a theoretical parameter disregarding plant efficiency and other fundamental parameters as reported above. Unlike exergy ex, the exploitable power $\dot{W}_{e}$ evaluated by Eq. (6) gives more complete information about energetic potential. For a given aquifer, such parameter accounts for the best plant option, the available exergy and flow rate, and the maximum electrical power which can be produced.

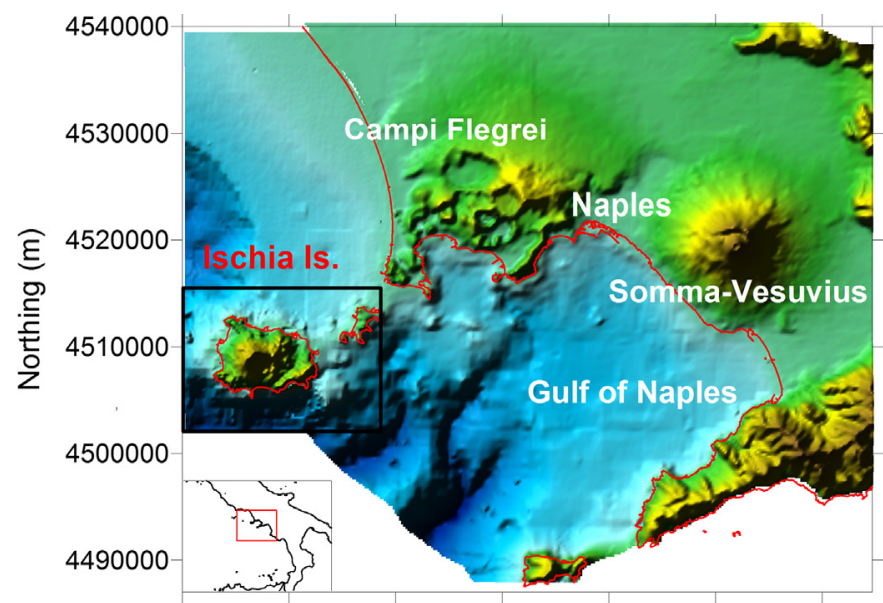

(a)

400000410000420000430000440000450000460000

Easting $(\mathrm{m})$
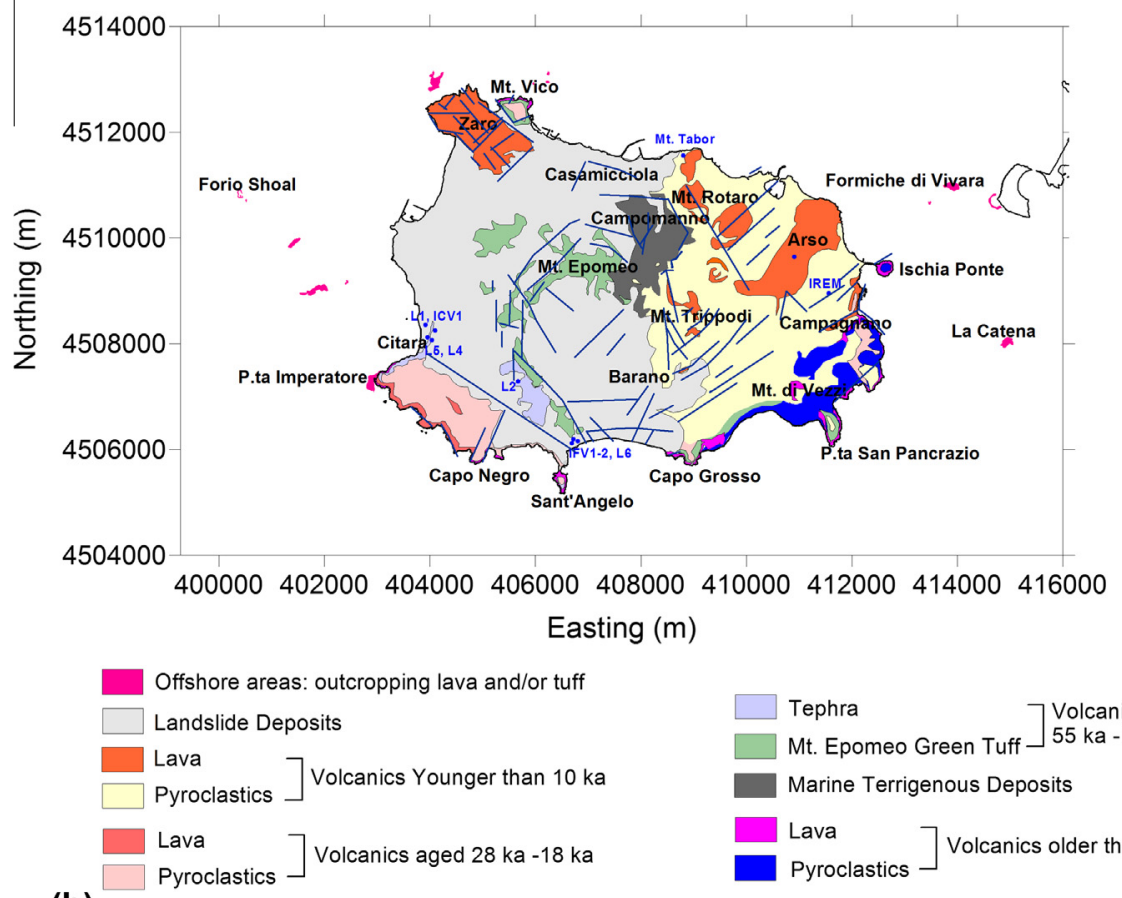

(b)

- Thermal wells $/$ Faults

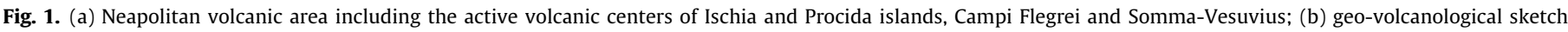
maps of Ischia with location of faults and thermal well of the island. Modified after [33]. 
Table 1

Ischia geothermal data set used in our analysis.

\begin{tabular}{|c|c|c|c|c|c|c|c|c|c|c|}
\hline $\begin{array}{l}\text { Sample } \\
\#\end{array}$ & $\begin{array}{l}X(\mathrm{~m}(\mathrm{UTM} \\
\text { WGS 84)) }\end{array}$ & $\begin{array}{l}Y(\mathrm{~m}(\mathrm{UTM} \\
\text { WGS 84)) }\end{array}$ & $\begin{array}{l}\text { Well depth } \\
L w(\mathrm{~m})\end{array}$ & $\begin{array}{l}\text { Static head } \\
\mathrm{Hs}(\mathrm{M})\end{array}$ & $\begin{array}{l}\text { Water flow rate } \\
(\dot{m})(1 / s)\end{array}$ & $\begin{array}{l}\text { Temperature } \\
t\left({ }^{\circ} \mathrm{C}\right)\end{array}$ & $\begin{array}{l}\text { Enthalpy } h_{a q} \\
(\mathrm{~kJ} / \mathrm{kg})\end{array}$ & $\begin{array}{l}\mathrm{NCG} \mathrm{C}_{\mathrm{O}_{2}} \\
\left(\mathrm{Ncm}^{3} / \mathrm{l}\right) \\
\end{array}$ & $\begin{array}{l}\mathrm{NCG} C_{\mathrm{N}_{2}} \\
\left(\mathrm{Ncm}^{3} / \mathrm{l}\right) \\
\end{array}$ & 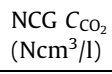 \\
\hline 2 & 407,895 & $4,510,888$ & & & & 53.3 & 223.51 & 1.94 & 11.21 & 52.76 \\
\hline 3 & 405,807 & $4,510,861$ & 140 & & 0.84 & 57.5 & 241.33 & 0.03 & 7.21 & 133.89 \\
\hline 5 & 409,441 & $4,511,359$ & 30 & 0.88 & 15 & 72.3 & 303.13 & 3.07 & 7.34 & 38.45 \\
\hline 6 & 409,441 & $4,511,359$ & 30 & & 15 & 58.8 & 246.60 & 2.57 & 1.31 & 28.09 \\
\hline 7 & 407,503 & $4,511,409$ & & 31.74 & 4.76 & 28.1 & 118.18 & 3.05 & 14.31 & 14.18 \\
\hline 11 & 407,605 & $4,511,542$ & 30 & 14 & 6 & 27.5 & 115.65 & 1.10 & 13.86 & 12.35 \\
\hline 12 & 406,347 & $4,510,740$ & & & & 67.0 & 280.85 & 1.21 & 6.38 & 158.66 \\
\hline 13 & 407,722 & $4,510,703$ & & & & 55.8 & 233.97 & 5.03 & 14.38 & 44.93 \\
\hline 14 & 408,247 & $4,511,075$ & 130 & & 1.67 & 49.9 & 210.18 & & & \\
\hline 15 & 408,249 & $4,511,077$ & & & & 18.7 & 78.870 & & & \\
\hline 16 & 406,791 & $4,511,051$ & 96.5 & 85.6 & 2 & 47.4 & 198.78 & 0.76 & 9.29 & 54.11 \\
\hline 17 & 406,791 & $4,511,051$ & 96 & 85.1 & 3 & 45.2 & 189.58 & 1.04 & 9.64 & 31.09 \\
\hline 23 & 406,903 & $4,511,110$ & 80 & & & 38.3 & 161.34 & 1.57 & 11.83 & 32.46 \\
\hline 24 & 406,728 & $4,510,950$ & & & & 61.6 & 258.24 & 5.13 & 14.78 & 57.50 \\
\hline 25 & 406,740 & $4,510,967$ & & & & 53.4 & 223.93 & 2.73 & 15.46 & 28.20 \\
\hline 26 & 406,757 & $4,510,981$ & & & & 50.8 & 213.06 & 4.96 & 13.72 & 15.24 \\
\hline 27 & 407,722 & $4,510,703$ & & & & 57.0 & 238.99 & & & \\
\hline 28 & 407,725 & $4,510,706$ & & & & 58.0 & 243.17 & 4.73 & 11.06 & 2.83 \\
\hline 29 & 408,701 & $4,511,600$ & 27.1 & 17.55 & 3.7 & 44.9 & 188.36 & 2.18 & 13.50 & 22.94 \\
\hline 30 & 407,015 & $4,510,750$ & 147 & 130 & 5 & 46.1 & 193.56 & 1.43 & 19.80 & 74.88 \\
\hline 31 & 406,980 & $4,510,805$ & 247 & 130 & 2 & 58.3 & 246.34 & 0.36 & 7.87 & 121.13 \\
\hline 32 & 406,195 & $4,511,673$ & 33 & & 5 & 73.0 & 305.98 & 0.89 & 1.93 & 231.07 \\
\hline 33 & 406,212 & $4,511,704$ & 36 & 14 & 1.8 & 47.0 & 197.20 & 0.77 & 8.37 & 238.89 \\
\hline 34 & 404,478 & $4,511,533$ & 38 & 10.5 & 5 & 33.9 & 142.58 & 0.30 & 14.69 & 12.01 \\
\hline 35 & 405,911 & $4,511,903$ & 60 & 7.46 & 6.25 & 63.5 & 266.48 & 2.14 & 8.58 & 344.06 \\
\hline 36 & 405,945 & $4,511,995$ & 50 & 14 & 2.4 & 58.2 & 244.26 & 0.66 & 5.95 & 331.65 \\
\hline 47 & 409,562 & $4,509,135$ & & & & 21 & 88.493 & 6.71 & 17.26 & 2.96 \\
\hline 48 & 410,790 & $4,509,236$ & 72 & 42.76 & 3.92 & 44.0 & 185.09 & 3.94 & 10.76 & 29.21 \\
\hline 49 & 409,821 & $4,511,012$ & 80 & 56.3 & 3.3 & 33.9 & 142.47 & 1.98 & 13.64 & 24.40 \\
\hline 50 & 412,151 & $4,508,976$ & 24 & & 4 & 26.4 & 111.08 & 0.00 & 10.76 & 179.61 \\
\hline 51 & 411,266 & $4,510,487$ & & 31.77 & 4.17 & 52.6 & 220.58 & 0.05 & 2.73 & 331.25 \\
\hline 52 & 410,971 & $4,510,782$ & & & 2.55 & 39.0 & 163.73 & 0.94 & 11.48 & 25.64 \\
\hline 53 & 411,170 & $4,510,771$ & 39.5 & 13 & 8.33 & 31.5 & 132.57 & 3.83 & 10.31 & 12.96 \\
\hline 54 & 412,106 & $4,508,896$ & 40 & & 4.75 & 34.8 & 146.16 & 0.28 & 5.48 & 476.72 \\
\hline 55 & 412,106 & $4,509,017$ & 65 & 50.3 & 6.67 & 34.5 & 144.88 & 3.66 & 11.78 & 82.41 \\
\hline 56 & 409,724 & $4,508,808$ & 200 & 194.59 & 2 & 75.4 & 315.96 & 0.61 & 3.09 & 249.69 \\
\hline 57 & 410,138 & $4,507,704$ & & & & 40.0 & 167.91 & 0.28 & 4.51 & 56.23 \\
\hline 58 & 411,768 & $4,510,002$ & 40 & & 5 & 33.4 & 140.51 & 0.42 & 5.58 & 400.76 \\
\hline 59 & 411,036 & $4,510,874$ & 45 & 11 & 2 & 42.8 & 179.83 & 0.04 & 7.56 & 297.66 \\
\hline 60 & 411,500 & $4,510,700$ & 24 & & 3.6 & 26.3 & 110.69 & 0.03 & 10.87 & 190.41 \\
\hline 61 & 411,169 & $4,509,661$ & 70 & 33.15 & 3.33 & 39.6 & 166.40 & 0.62 & 6.70 & 447.51 \\
\hline 62 & 410,729 & $4,509,408$ & 60 & 41.5 & 4.17 & 56.4 & 236.48 & 3.49 & 15.46 & 84.41 \\
\hline 63 & 409,081 & $4,509,659$ & & & & 13.5 & 57.097 & 6.46 & 15.81 & 3.24 \\
\hline 64 & 412,096 & $4,508,750$ & & & & 37.6 & 157.88 & & & \\
\hline 65 & 409,832 & $4,509,363$ & & & & 31.5 & 132.39 & 5.53 & 12.10 & 4.41 \\
\hline 66 & 411,069 & $4,508,945$ & & & & 43.5 & 182.54 & 0.07 & 6.63 & 217.85 \\
\hline 67 & 410,740 & $4,510,614$ & 36 & & 4.17 & 48.1 & 201.91 & 0.19 & 13.24 & 126.72 \\
\hline 68 & 410,740 & $4,510,614$ & 12 & & 3.33 & 46.5 & 195.01 & 4.57 & 15.33 & 43.61 \\
\hline 69 & 410,427 & $4,510,744$ & 20 & 15.5 & 2.5 & 41.3 & 173.35 & 0.57 & 9.27 & 249.91 \\
\hline 70 & 404,089 & $4,508,867$ & 70 & 51.45 & 3.15 & 69.0 & 289.26 & 2.20 & 6.91 & 229.09 \\
\hline 71 & 404,432 & $4,509,971$ & 70 & 29.8 & 2.5 & 23.9 & 100.84 & 3.04 & 15.09 & 8.45 \\
\hline 72 & 404,217 & $4,508,431$ & 100 & 59.4 & 2.64 & 74.0 & 310.82 & 0.72 & 3.66 & 162.95 \\
\hline 73 & 403,803 & $4,509,476$ & 190 & 46.84 & 3.6 & 46.0 & 194.10 & 0.30 & 12.48 & 16.96 \\
\hline
\end{tabular}


Table 1 (continued)

\begin{tabular}{|c|c|c|c|c|c|c|c|c|c|c|}
\hline $\begin{array}{l}\text { Sample } \\
\#\end{array}$ & $\begin{array}{l}X(\mathrm{~m}(\mathrm{UTM} \\
\text { WGS 84)) }\end{array}$ & $\begin{array}{l}Y(\mathrm{~m}(\mathrm{UTM} \\
\text { WGS 84)) }\end{array}$ & $\begin{array}{l}\text { Well depth } \\
L w(\mathrm{~m})\end{array}$ & $\begin{array}{l}\text { Static head } \\
\text { Hs (M) }\end{array}$ & $\begin{array}{l}\text { Water flow rate } \\
(\dot{m})(\mathrm{l} / \mathrm{s})\end{array}$ & $\begin{array}{l}\text { Temperature } \\
t\left({ }^{\circ} \mathrm{C}\right)\end{array}$ & $\begin{array}{l}\text { Enthalpy } h_{a q} \\
(\mathrm{~kJ} / \mathrm{kg})\end{array}$ & $\begin{array}{l}\mathrm{NCG} \mathrm{C}_{\mathrm{O}_{2}} \\
\left(\mathrm{Ncm}^{3} / \mathrm{l}\right)\end{array}$ & $\begin{array}{l}\operatorname{NCG~} C_{\mathrm{N}_{2}} \\
\left(\mathrm{Ncm}^{3} / 1\right)\end{array}$ & $\begin{array}{l}\mathrm{NCG} C_{\mathrm{CO}_{2}} \\
\left(\mathrm{Ncm}^{3} / \mathrm{l}\right)\end{array}$ \\
\hline 74 & 404,102 & $4,508,413$ & & & & 75.0 & 314.37 & 1.47 & 5.70 & 74.81 \\
\hline 75 & 404,469 & $4,508,817$ & 143 & & 4.17 & 70.1 & 294.06 & 1.84 & 6.29 & 203.59 \\
\hline 76 & 404,826 & $4,508,343$ & 183 & 107.5 & 2.5 & 73.4 & 308.16 & 1.73 & 4.36 & 188.29 \\
\hline 77 & 404,401 & $4,508,392$ & 140 & 95 & 2.5 & 61.3 & 257.36 & 1.73 & 5.77 & 58.04 \\
\hline 78 & 404,146 & $4,508,760$ & 100 & & 5 & 63.7 & 267.69 & 0.80 & 5.35 & 200.34 \\
\hline 79 & 403,947 & $4,508,131$ & & & & 79.9 & 334.92 & 1.33 & 6.36 & 62.31 \\
\hline 80 & 403,814 & $4,508,046$ & 35 & 4.5 & & 25.6 & 107.87 & 3.06 & 12.04 & 4.18 \\
\hline 81 & 404,518 & $4,509,703$ & & & & 21.3 & 89.748 & 4.73 & 12.77 & 7.68 \\
\hline 82 & 403,911 & $4,508,453$ & & & & 96.7 & 405.55 & & & \\
\hline 83 & 404,667 & $4,509,913$ & & & & 40.0 & 167.91 & 2.76 & 7.54 & 2.65 \\
\hline 84 & 404,037 & $4,509,512$ & & & & 34.8 & 146.18 & 0.00 & 15.00 & 87.80 \\
\hline 85 & 404,035 & $4,509,510$ & 50 & 48.75 & 3.28 & 21.7 & 91.309 & 3.52 & 19.23 & 19.80 \\
\hline 86 & 404,137 & $4,508,899$ & & & & 41.0 & 172.09 & 0.25 & 9.22 & 198.53 \\
\hline 87 & 404,201 & $4,508,354$ & & & & 70.6 & 295.93 & 3.32 & 15.19 & 122.24 \\
\hline 88 & 404,140 & $4,508,356$ & 150 & 56.56 & 2.4 & 72.5 & 304.49 & 5.42 & 22.03 & 39.12 \\
\hline 89 & 404,182 & $4,508,724$ & 90 & 68 & 3.33 & 76.4 & 320.80 & 0.56 & 3.33 & 171.15 \\
\hline 90 & 404,455 & $4,510,046$ & 10 & & & 33.5 & 140.66 & 3.80 & 10.09 & 12.68 \\
\hline 91 & 404,700 & $4,508,039$ & 120 & & 3 & 61.4 & 257.87 & 1.69 & 5.06 & 31.73 \\
\hline 92 & 404,565 & $4,506,783$ & & & & 70.8 & 296.76 & 1.09 & 4.28 & 50.95 \\
\hline 93 & 405,406 & $4,506,467$ & 110 & & 4 & 90.0 & 377.50 & 1.48 & 5.16 & 15.13 \\
\hline 94 & 405,404 & $4,507,131$ & 150 & 132.55 & 3 & 73.2 & 306.91 & 1.83 & 6.00 & 63.88 \\
\hline 95 & 404,021 & $4,506,597$ & 50 & & 2.44 & 47.0 & 197.43 & 1.16 & 13.32 & 6.02 \\
\hline 96 & 403,979 & $4,506,621$ & & & & 36.6 & 153.70 & 0.85 & 12.57 & 7.06 \\
\hline 97 & 405,738 & $4,507,607$ & & & & 18.3 & 77.196 & 4.64 & 13.65 & 3.17 \\
\hline 98 & 405,201 & $4,505,977$ & & & & 82.9 & 347.52 & 5.35 & 21.63 & 66.96 \\
\hline 99 & 406,689 & $4,506,121$ & 100 & & 5 & 60.1 & 252.63 & 0.04 & 14.60 & 3.71 \\
\hline 100 & 406,710 & $4,506,036$ & 23 & 19.5 & 3.33 & 49.3 & 206.65 & 0.50 & 12.55 & 37.09 \\
\hline 101 & 406,781 & $4,506,052$ & & & & 83.8 & 351.30 & 1.12 & 7.39 & 30.61 \\
\hline 102 & 406,783 & $4,506,055$ & & & & 84.4 & 353.82 & 6.14 & 21.04 & 55.15 \\
\hline 103 & 405,976 & $4,506,453$ & 80 & 62 & 2 & 80.5 & 337.92 & 5.90 & 20.97 & 0.35 \\
\hline 104 & 406,211 & $4,506,309$ & & & & 85.3 & 357.60 & 5.37 & 20.53 & 0.26 \\
\hline 105 & 406,512 & $4,505,946$ & 97 & 48.16 & 6.17 & 45.9 & 192.85 & 2.91 & 9.43 & 23.91 \\
\hline 106 & 406,176 & $4,506,075$ & & & & 77.5 & 324.85 & 3.46 & 12.59 & 39.02 \\
\hline 107 & 405,929 & $4,506,546$ & 90 & & 4.4 & 78.0 & 326.97 & 1.90 & 5.04 & 0.94 \\
\hline 108 & 407,457 & $4,506,497$ & & & & 74.0 & 310.18 & 4.50 & 14.68 & 86.73 \\
\hline 109 & 407,461 & $4,506,483$ & & & & 56.0 & 234.81 & 2.51 & 6.70 & 10.16 \\
\hline 110 & 407,601 & $4,506,215$ & 30 & & 1.3 & 85.9 & 360.17 & 0.80 & 3.61 & 48.73 \\
\hline 111 & 408,224 & $4,506,401$ & 40 & 16.5 & 3.33 & 79.0 & 331.31 & 2.29 & 7.95 & 41.55 \\
\hline 112 & 407,639 & $4,506,336$ & & & & 52.2 & 218.91 & 0.97 & 8.59 & 388.83 \\
\hline 113 & 407,679 & $4,506,487$ & & & & 40.0 & 167.91 & & & \\
\hline 114 & 407,681 & $4,506,490$ & & & & 25.9 & 108.98 & 0.06 & 14.07 & 71.16 \\
\hline 115 & 408,117 & $4,506,133$ & & & & 67.2 & 281.68 & 0.91 & 7.33 & 62.52 \\
\hline 116 & 408,319 & $4,506,287$ & & & & 79.7 & 334.08 & 2.55 & 7.62 & 42.53 \\
\hline 117 & 407,818 & $4,506,271$ & 46 & 26.5 & 4.17 & 70.5 & 295.72 & 1.12 & 2.70 & 192.03 \\
\hline 118 & 408,569 & $4,506,466$ & 180 & 160.95 & 1.33 & 72.6 & 304.48 & 1.01 & 5.11 & 161.92 \\
\hline 119 & 408,053 & $4,507,292$ & & & & 28.2 & 118.60 & 4.08 & 10.57 & 135.86 \\
\hline 120 & 408,637 & $4,506,408$ & 140 & 105 & 3.33 & 45.2 & 190.69 & 1.96 & 7.42 & 185.35 \\
\hline 121 & 407,930 & $4,506,160$ & & & & 91.0 & 381.56 & 0.13 & 2.25 & 118.51 \\
\hline
\end{tabular}

\section{Case study: the Ischia volcanic island}

\subsection{Introduction}

We applied our method to a real case (volcanic island of Ischia, Southern Italy, Fig. 1a) with the aim of showing that our analysis accounts for more information (i.e., the flow rate) than the exergetic analysis and gives a tangible prevision of electrical power available from a geosource. The geomorphological setting of the island reflects the complex volcano-tectonic history experienced by Ischia in the past 150,000 years $[24,25]$. The large Mt. Epomeo Green Tuff eruption that took place 55,000 years ago (MEGT, [26]) is considered a benchmark in the volcano's evolution. This event was followed by resurgence and uplift of the Mt. Epomeo block (altitude $787 \mathrm{~m}$ ), the highest relief of the island [28]. Volcanic rocks from both effusive and explosive eruptions contained in outcrops on Ischia are associated with marine and landslide deposits resulting from surface gravitational movements [29,30] (Fig. 1b). We refer to [28] for a more detailed description of the activity and products of the island, and to [31,32] for a description of geochemical and geophysical investigations at Ischia.

\subsection{Geothermal framework}

Since the 1302 A.D. Arso eruption [27], the Ischia volcano has entered phase of quiescence. The still active nature of the volcano creating vigorous hydrothermal circulation beneath Ischia, is testified by the intense seismicity [30]; and by numerous numerous fumarolic gas emissions and hot water discharges widespread over the entire island (e.g., [33-36]).

Scientific interest for Ischia's hydrothermal system started in the 50's, when an explorative drilling program was launched by S.A.F.E.N. (Società Anonima Forze Endogene Napoletane) [36]. About 100 wells were drilled down to a depth of $1156 \mathrm{~m}$ in the western and southern sectors of the island, demonstrating high subsurface temperatures from $T>70^{\circ} \mathrm{C}$ at the free-water surface up to $225^{\circ} \mathrm{C}$ at $\sim 1 \mathrm{~km}$ depth [37,38]. Since the early 80's, numerous geochemical investigations on surface thermal manifestations (shallow thermal waters and fumarolic gas emissions) were conducted, with the aim of extracting information about the structures of the deep hydrothermal system and fluid circulation dynamics. According to these studies [33,39,34-36], both cold $\left(\sim 15^{\circ} \mathrm{C}\right)$ and hot (up to $100{ }^{\circ} \mathrm{C}$ ) geofluids coexist on Ischia. The northern and 
southwestern sectors were identified as the most thermalized areas $\left(T \geqslant 80^{\circ} \mathrm{C}\right)$; while geofluids with temperatures of $<50^{\circ} \mathrm{C}$ were encountered in the eastern part. Chemical data suggest that the Ischia hydrothermal system is recharged by infiltrating meteoric waters mainly in the inland areas and by seawater along coastal areas ([36] and references therein).

Upon infiltration, these cold waters react and equilibrate with host rock formations at temperatures ranging from $150{ }^{\circ} \mathrm{C}$ to $280^{\circ} \mathrm{C}$. Data from explorative drillings $[37,38]$ and geothermometric studies performed on surface manifestations [33,40,34] have concurred to reveal the existence of at least two superposed reservoirs. The shallow reservoir (150-300 $\mathrm{m}$ of depth) has temperatures of $150-180^{\circ} \mathrm{C}$ and is thought to be recharged by meteoric water mainly in the southern sector and by marine fluids in the western part of the island ([36] and references therein). The deeper hydrothermal reservoir, probably located at about $1000 \mathrm{~m}$ depth is characterized by temperatures of $220-280{ }^{\circ} \mathrm{C}$ and has a prevalent meteoric water recharge [34]. A dense network of faults and structural discontinuities promotes the ascent of deeply equilibrated reservoir fluids into the shallow geofluid system. The mixing between deep rising hot fluids and cold infiltrating waters determines the wide spectrum of Ischia's thermal water compositions $[34,36]$. Chemical and isotopic measurements on fumaroles and dissolved gases in geofluids concur to suggest that the hydrothermal system is currently supplied with a $\mathrm{CO}_{2}$-rich gas phase of deep, magmatic origin [34,41]. These magma-derived volatiles are possibly sourced by the degassing of a $1000{ }^{\circ} \mathrm{C}$ trachytic magma at around a $2 \mathrm{~km}$ depth [42]. The presence of high temperatures below the island is also confirmed by the lack of a clear magnetic signature over the central sector of Ischia $[31,32]$. This is possibly due to the hydrothermal alteration phenomena of the igneous materials and/or the presence of partially molten areas inside the island's magmatic basement.

\subsection{Application of the method}

In order to quantify the power potential of the Ischia geothermal system, we use data taken from [34]. We extracted a data set of 121 water samples collected from wells exploited in spas and hotels, as reported in Table 1. This data, acquired from 2002 to 2007, was obtained using traditional analytical techniques in geothermal exploration. Temperature measurements (expressed in ${ }^{\circ} \mathrm{C}$ ) were determined in the field by portable instruments, while gas chromatography (at Istituto Nazionale di Geofisica e Vulcanologia (INGV), Sezione di Palermo) was used to determine concentrations of dissolved gases $\left(\mathrm{O}_{2}, \mathrm{~N}_{2}\right.$ and $\left.\mathrm{CO}_{2}\right)$ in water samples (expressed as $\mathrm{cm}^{3} / 1$ at standard temperature and pressure - STP). For more details on sampling and analytical methods, see Ref. [34]. Hydrogeological data (depth and flow rate) were extracted from information available at Ufficio Settore Acque Minerali e Termali, Regione Campania. Depth of wells $L_{w}$ (in $\mathrm{m}$ ) refer to the depth at which the aquifer was encountered during drilling operations. In all cases, the data refers to the shallower of the two reservoirs of the island. Flow rate $(1 / \mathrm{s})$ was measured at regime (e.g., after drilling operation were terminated).

Thus, all values of Table 1 were measured except for the enthalpy values, which were calculated starting from temperature and water pressure data. Water pressure was evaluated by Eq. (10) for all cases in which well depth $L_{w}$ and static head $H_{s}$ were available. For all other cases, we adopted a mean pressure value of $0.2 \mathrm{MPa}$ for the enthalpy calculation. This approximation is acceptable considering that the available pressure values vary in a restricted range, which implies a limited influence on enthalpy values.

Data reported in Table 1 were gridded to an interval of $85 \mathrm{~m}$ using the Minimum Curvature algorithm in order to obtain spatial distribution maps for the considered parameters (Fig. 2). The distribution map of dissolved gas amounts $\left(\mathrm{O}_{2}+\mathrm{N}_{2}+\mathrm{CO}_{2}\right)$ (Fig. 2a)
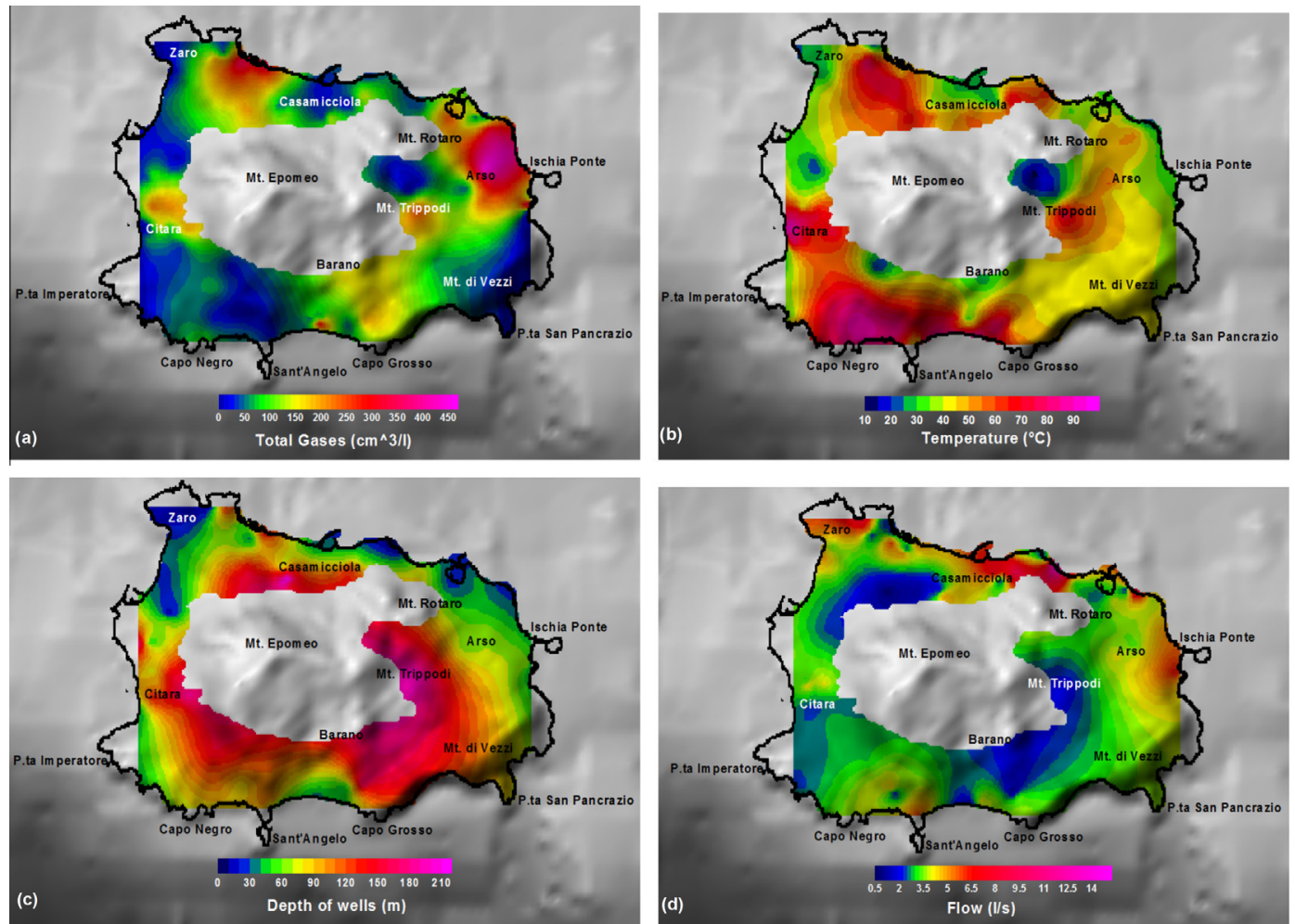

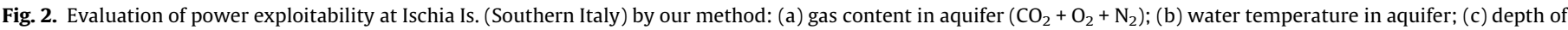
wells; (d) water flow rate. 

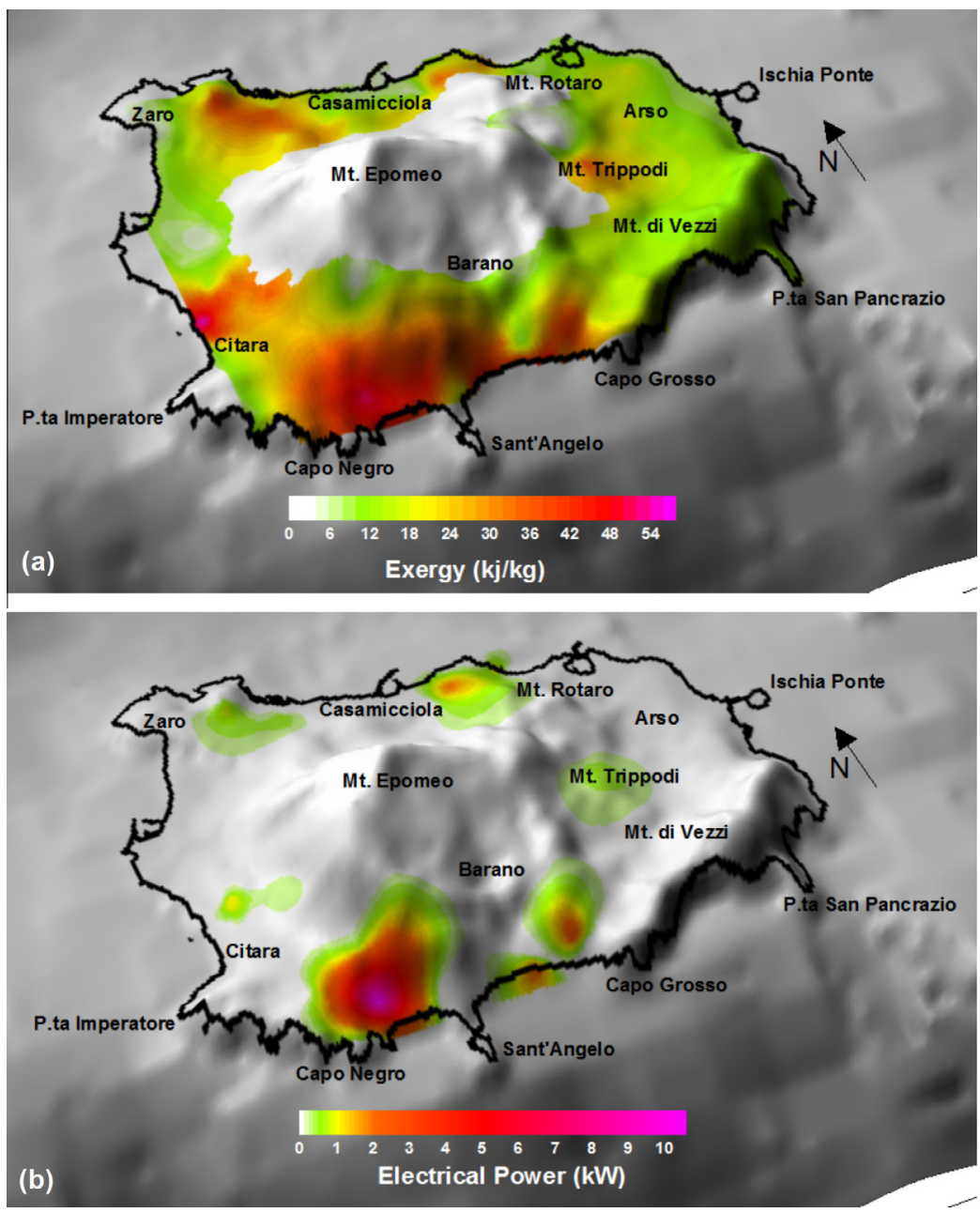

Fig. 3. Application of the proposed method to the Ischia Is.: (a) exergy Map; black squares show data location. (b) Map of the exploitable power distribution.

indicates that the higher concentrations of non-condensable gas, from $200 \mathrm{~cm}^{3} / 1$ up to $400 \mathrm{~cm}^{3} / 1$ at STP, are observed in geofluids circulating in the NW- and in the SW-sectors, and mainly in the eastern area of the island. Fig. $2 \mathrm{~b}$ shows that a significant temperature anomaly $\left(T>70^{\circ} \mathrm{C}\right)$ is identified in the NW, NE and SWsectors of Ischia island, where boreholes not deeper than $100 \mathrm{~m}$ (Fig. 2c) tap the $100^{\circ} \mathrm{C}$ shallow aquifer [34,35]. On the contrary, at the same depth, wells located in the eastern sector show lower temperature geofluids $\left(T<50^{\circ} \mathrm{C}\right.$ ) (compare Fig. $2 \mathrm{~b}$ and c). Whereas, only at $200 \mathrm{~m}$ of depth from the ground level in the Mt. Trippodi area, the geofluid temperature reaches $75^{\circ} \mathrm{C}$ (Fig. 2b and c). Water flow rates range from 3.5 to $5 \mathrm{l} / \mathrm{s}$ in nearly all coastal sites (Fig. 2d), while larger flow rates up to $11 \mathrm{l} / \mathrm{s}$ are identified in the NE sector.

From an energetic point of view, considering the case at Ischia island, the temperature and flow rate are certainly the most important parameters. The influence of total gas content and well depth that according to Eq. (6), penalizes exploitable power is in fact, close to being negligible.

In Fig. 3 we show a comparison of the exergy map and the electrical exploitable $\dot{W}_{e}$ power for the island derived by Eqs. (2) and (6) respectively, accounting for the data in Table 1 . The electrical exploitable power map (Fig. 3b) highlights that only a few restricted areas of island (the NE and SW sectors) are suitable for electrical power generation from low enthalpy geothermal sources. This outcome is related to the coexistence of adequate enthalpies and suitable flow rates that characterize these zones of the island. On the contrary, in many zones of the island, the ground water enthalpy is lower than the minimum adequate level (for the installation of a power plant) of $300 \mathrm{~kJ} / \mathrm{kg}$, as reported in Table 1 . We note that the areas of Citara, Zaro-Casamicciola and Trippodi, which are of considerable exergy (Fig. 3a) are instead, highlighted by our method as not suitable for power production due to a low flow rate (see Figs. 2d and 3b).

We conclude that the proposed method gives more detailed information about geothermal power exploitability than an exergetic analysis and allows a clear identification of the areas of interest where plant installation is economically feasible and cost effective.

We add that, based on enthalpy values that are always below $405 \mathrm{~kJ} / \mathrm{kg}$ (see $h_{a q}$ in Table 1 ), the best plant option for all energetically exploitable areas of the island falls into the category of binary plants.

\section{Concluding remarks}

Geothermal resources have a great potential for exploitability all over the world. Technologies for geothermal electrical power production have advanced significantly during the last decades but much work remains to be done for the analysis of sites of geothermal interest.

Exergetic analysis of a geothermal resource is now a consolidated method to quantify the resource potential for producing mechanical energy. Electrical energy production from geothermal sources is realized through different techniques, such as single flash 
and double flash, dry steam, and binary ORC plants. The technique chosen to be the most productive is determined by analyzing a specific range of geofluid properties, mainly temperature and pressure. Moreover, each plant typology has a global efficiency which depends on geofluid enthalpy. Such correlation is reported in literature, i.e. [8], and is based on efficiency values of almost all plants of that typology in the world. The proposed evaluation method brings together all these correlations, yielding the power availability from a geosource, once its temperature and pressure are known. The method takes as input the available geofluid flow rate, its pressure, temperature and non-condensable gases content. It defines the best plant option from these parameters, calculates its global efficiency and finally returns the actual available power. For sites of geothermic interest, such as Ischia, for which a large dataset is available, the results of the application of this new method highlight the most suitable zones for power plant installations.

The proposed method is based on empiric equations and gives a more realistic analysis than the exergetic analysis. Actually, our analysis may be viewed as a possible alternative to the exergetic one, as it accounts for more information (such as the flow rate) and gives a tangible prevision of electrical power available from a geosource. This leads to a clear identification of the areas of interest, where plant installation is economically feasible and cost effective.

The method proposed here represents a useful tool to process geothermal data in order to identify the most interesting areas and predict the electrical power which can be produced. This can be a first screening step in a technical and economic feasibility analysis preliminary to plant installation. A discriminating factor for this approach is the availability of data which is often poor and/or expensive. The application of the method to Ischia, highlighted suitability for electrical power generation in the SW and NE sectors of the island. A further upgrade of the method can be the economic analysis of geothermal power production whose study can be locally focused on the basis of incentives to renewable energy exploitation.

\section{Acknowledgements}

We are indebted to two anonymous reviewers for their comments and suggestions that greatly helped to improve our manuscript. We are grateful to David Giampietro for language revision.

\section{References}

[1] GEA - Geothermal Energy Association. Annual U.S and global geotherma power production report; 2014. 25 pp.

[2] Di Pippo R. Geothermal power plants: evolution and performance assessments. Geothermics 2015;53:291-307.

[3] Holdmann G, List K. The Chena hot springs $400 \mathrm{~kW}$ geothermal power plant: experience gained during the first year of operation. Geotherm Res Council Trans 2007;31:515-9.

[4] Ziviani D, Beyene A, Venturini M. Advances and challenges in ORC systems modeling for low grade thermal energy recovery. Appl Energy 2014;121:79-95. http://dx.doi.org/10.1016/i.apenergy.2014.01.074.

[5] Calise F, Cipollina A, Dentice d'Accadia M, Piacentino A. A novel renewable polygeneration system for a small Mediterranean volcanic island for the combined production of energy and water: dynamic simulation and economic assessment. Appl Energy 2014. http://dx.doi.org/10.1016 j.apenergy.2014.03.064 [available online 24.04.14]

[6] Ibrahim R, Fauzi A, Darma S. The progress of geothermal energy resources activities in Indonesia. Antalya: World Geothermal Congress; 2005. p. 1-7.

[7] Kaya E, Zarrouk SJ, O'Sullivan MJ. Reinjection in geothermal fields: a review of worldwide experience. Renew Sustain Energy Rev 2011;15:47-68.

[8] Zarrouk SJ, Moon H. Efficiency of geothermal power plants: a worldwide review. Geothermics 2014;51:142-53.

[9] Pambudi NA, Itoi R, Jalilinasrabady S, Jaelani K. Exergy analysis and optimization of Dieng single-flash geothermal power plant. Energy Convers Manage 2014;78:405-11.

[10] Di Pippo R. Geothermal double-flash plant with interstage reheating: an updated and expanded thermal and exergetic analysis and optimization. Geothermics 2013;48:121-31.

[11] El-Emam RS, Dincer I. Exergy and exergoeconomic analyses and optimization of geothermal organic Rankine cycle. Appl Therm Eng 2013;59:435-44.
[12] Franco A, Vaccaro M. Numerical simulation of geothermal reservoirs for the sustainable design of energy plants: a review. Renew Sustain Energy Rev 2014;30:987-1002.

[13] Quattrocchi F, Boschi E, Spena A, Buttinelli M, Cantucci B, Procesi M. Synergic and conflicting issues in planning underground use to produce energy in densely populated countries, as Italy: geological storage of $\mathrm{CO}_{2}$, natural gas, geothermics and nuclear waste disposal. Appl Energy 2013;101:393-412. http://dx.doi.org/10.1016/i.apenergy.2012.04.028.

[14] Flores JR, Montagna JM, Vecchietti A. An optimization approach for long term investments planning in energy. Appl Energy 2014;122:162-78. http:/l dx.doi.org/10.1016/j.apenergy.2014.02.002.

[15] Lashina A, Al Arific N. Geothermal energy potential of southwestern of Saudi Arabia "exploration and possible power generation": a case study at Al Khouba area - Jizan. Renew Sustain Energy Rev 2014;30:771-89.

[16] Di Pippo R. Geothermal power plants: principles, application, case studies and environmental impact. 3rd ed. Waltham (MA, USA): Elsevier Ltd.; 2012.

[17] Lee KC. Classification of geothermal resources by exergy. Geothermics 2001;30:431-42.

[18] Barbacki A. Classification of geothermal resources in Poland by exergy analysis - comparative study. Renew Sustain Energy Rev 2012;16:123-8.

[19] Etemoglu AB, Can M. Classification of geothermal resources in Turkey by exergy analysis. Renew Sustain Energy Rev 2007;11:1596-606.

[20] Vorum M, Fitzler E. Comparative analysis of alternative means for removing noncondensable gases from flashed-steam geothermal power plants. Golden (CO, USA): National Renewable Energy Lab; 2000.

[21] Hudson RB. Technical and economic overview of geothermal atmospheric exhaust and condensing turbines binary cycles and bi-phase plant. Geothermics 1988;17:51-74.

[22] Atlason R, Unnthorsson R. Ideal EROI (energy return on investment) deepens the understanding of energy systems. Energy 2014;67:241-5.

[23] Chennouf N, Negrou B, Dokkar B, Settou N. Valuation and estimation of geothermal electricity production using carbon dioxide as working fluid in the south of Algeria. Energy Proc 2013:36:967-76.

[24] Civetta L, Gallo G, Orsi G. Sr- and Nd-isotope and trace element constraints on the chemical evolution of the magmatic system of Ischia (Italy) in the last 55 ka. J Volcanol Geotherm Res 1991;46:213-30.

[25] Orsi G, de Vita S, di Vito M. The restless resurgent Campi Flegrei nested caldera (Italy): constraints on its evolution and configuration. J Volcanol Geotherm Res 1996;74:179-214.

[26] Brown RJ, Orsi G, de Vita S. New insights into Late Pleistocene explosive volcanic activity and caldera formation on Ischia (southern Italy). Bull Volcanol 2008;70:583-603.

[27] Buchner G. Eruzioni vulcaniche e fenomeni vulcano-tettonici di eta' preistorica e storica nell'isola d'Ischia. In: Eruptions Volcaniques, Tremblemants de Terre et Vie des Hommes dans la Campanie Antique, vol. 7, Centre J. Bérard, Inst. Fr. de Naples, Naples, Italy; 1986. p. 145-88 [in Italian].

[28] Orsi G, Gallo G, Zanchi A. Simple-shearing block resurgence in caldera depressions. A model from Pantelleria and Ischia. J Volcanol Geotherm Res $1991 ; 47: 1-11$

[29] de Vita S, Sansivero F, Orsi G, Marotta E. Cyclical slope instability and volcanism related to volcano-tectonism in resurgent calderas: the Ischia island (Italy) case study. Eng Geol 2006;86:148-65.

[30] Rapolla A, Paoletti V, Secomandi M. Seismically-induced landslide susceptibility evaluation: application of a new procedure to the island of Ischia, Campania Region, Southern Italy. Eng Geol 2010;114:10-25.

[31] Paoletti V, Di Maio R, Cella F, Florio G, Mocka K, Roberti N, et al. The Ischia Volcanic Island (Southern Italy): inferences from potential field data interpretation. J Volcanol Geotherm Res 2009;179:69-86.

[32] Paoletti V, D'Antonio M, Rapolla A. The structural setting of the Ischia Island (Phlegrean Volcanic District, Southern Italy): inferences from geophysics and geochemistry. J Volcanol Geotherm Res 2013;249:155-73. http://dx.doi.org/ 10.1016/i.jvolgeores.2012.10.002

[33] Panichi C, Bolognesi L, Ghiara MR, Noto P, Stanzione D. Geothermal assessment of the island of Ischia (Southern Italy) from isotopic and chemical composition of the delivered fluids. J Volcanol Geotherm Res 1992:49:329-48.

[34] Di Napoli R, Aiuppa A, Bellomo S, Busca L, D’Alessandro W, Gagliano Candela E, et al. A model for Ischia hydrothermal system: evidences from the chemistry of thermal geofluids. J Volcanol Geotherm Res 2009;186:133-59.

[35] Di Napoli R, Martorana R, Orsi G, Aiuppa A, Camarda M, De Gregorio S, et al. The structure of a hydrothermal system from an integrated geochemical, geophysical, and geological approach: the Ischia Island case study. Geochem Geophys Geosyst 2011;12:007017. http://dx.doi.org/10.1029/2010GC003476.

[36] Di Napoli R, Federico C, Aiuppa A, D’Antonio M, Valenza M. Quantitative models of hydrothermal fluid-mineral reaction: the Ischia case. Geochim Cosmochim Acta 2013;105:108-29. http://dx.doi.org/10.1016/i.gca.2012.11. $\underline{039}$.

[37] Penta F. Ricerche e studi sui fenomeni esalativi-idrotermali e il problema delle forze endogene. Ann Geofis 1954;8:1-94 [in Italian].

[38] Penta F, Conforto B. Risultati di sondaggi e di ricerche geominerarie nell'isola d'Ischia dal 1939 al 1943, nel campo del vapore, delle acque termali e delle'forze endogene' in generale. Ann Geofis 1951;4:159-91 [in Italian].

[39] Aiuppa A, Avino R, Brusca L, Caliro S, Chiodini G, D’Alessandro W, et al. Mineral control of arsenic content in thermal waters from volcano-hosted hydrothermal systems: insights from island of Ischia and Phlegrean Field (Campanian Volcanic Province, Italy). Chem Geol 2006;229:313-30. 
[40] Chiodini G, Avino R, Brombach T, Caliro S, Cardellini C, de Vita S, et al. Fumarolic and diffuse soil degassing West of Mount Epomeo, Ischia, Italy. J Volcanol Geotherm Res 2004;133:291-309.

[41] D’Antonio M, Tonarini S, Arienzo I, Civetta L, Dallai L, Moretti R, et al. Mantle and crustal processes in the magmatism of the Campania region: inferences from mineralogy, geochemistry, and $\mathrm{Sr}-\mathrm{Nd}-\mathrm{O}$ isotopes of young hybrid volcanics of the Ischia island (South Italy). Contrib Min Petrol 2013;165:1173-94. http://dx.doi.org/10.1007/s00410-013-0853-x.

[42] Moretti R, Arienzo I, Orsi G, Civetta L, D’Antonio M. The deep plumbing system of the Ischia island: a physico-chemical window on the fluid-saturated and $\mathrm{CO}_{2}$-sustained Neapolitan volcanism (Southern Italy). J Petrol 2013;54:951-84. http://dx.doi.org/10.1093/petrology/egt002. 